\title{
Fenomena Madzhab dan Sekte-sekte di Indonesia: Sebuah Studi Medan Dakwah
}

\author{
Fisher Zulkarnain \\ UIN Sunan Gunung Djati Bandung \\ E-mail: fisherzulkarnain@yahoo.com
}

\begin{abstract}
This writing presents the development of mazhab (Islamic school of thought and law) and sects in Indonesia, including discussion the sects that are considered deviating. From social-religious perspective, the development of mazhab and sects in Indonesia is correlated with the development of science and social-religious dynamics of one society. Looking from the perspective of mazhab, Muslim in Indonesia is not only concentrated to Sunni (Syafi'i, Maliki, Hanafi, and Hambali), but also to Syiah that began to reveal in 1990s. Meanwhile, from the development of sects, there is a more dynamic and progressive phenomenon, which frequently goes beyond Muslim's logic and belief. The revealing sects are actually not the development or extension of conventional sects in Islam, such as Qodiriyah, Jabariyah, and Asyariyah, anymore. The development of the sects has come to theologicalpluralist development. However, this writing is to assert that the recent occurrence phenomena of various sects in Indonesia is actually not something new, instead of the extension of mysticism practice.
\end{abstract}

\section{Kata Kunci:}

Madzhab, Sekte, Teologi

\section{A. Pendahuluan}

Dewasa ini, perkembangan madzhab dan sekte-sekte di Indonesia menunjukkan perkembangan yang dinamis. Dinamika madzhab dan sekte ini ditunjukkan bukan hanya dalam wacana diskusi, seminar, atau pun kuliah-kuliah semata, melainkan telah pada tataran praksis berupa penerapan dalam realitas kehidupan baik secara individu maupun kelompok (organisasi). Secara sosial-religius, berkembangnya wacana dan praktek madzhab dan sekte-sekte di Indonesia ini berkorelasi dengan perkembangan pengetahuan dan dinamika sosial keagamaan masyarakat itu sendiri. 
Sebagaimana diketahui bahwa sejak Islam masuk dan menyebar di Indonesia, corak aliran yang berkembang adalah sunni, khususnya dari kalangan madzhab Syafii. Setidaknya penganut madzhab Syafi'i ini terlihat di sebagian besar wilayah di Indonesia.

Namun pada era 90-an terdapat polarisasi yang berbeda, dimana muslim di Indonesia bukan lagi terkonsentrasi hanya pada Sunni (khususnya Syafi'i), tetapi juga telah muncul madzhab lain termasuk dari kelompok Syiah. Ketika diselenggarakan sebuah seminar nasional di Jakarta (1 September 1997) yang dihadiri pejabat pemerintah, ABRI, MUI, pimpinan ormas Islam, dan masyarakat umum, maka keluarlah kesimpulan agar Kejaksaan Agung melarang Syiah, termasuk penyebaran buku-buku Syiah di Indonesia. Namun dalam perkembangannya, justru kecenderungan untuk mempelajari Syi'ah makin meningkat. Buku-buku tentang Syiah pun dengan mudah bisa diperoleh di toko-toko buku. Bahkan lembaga atau komunitas Syiah juga berkembang pesat.

Sementara dari segi perkembangan sekte-sekte, terdapat fenomena yang berbeda dimana dinamika yang muncul kerap melampaui nalar dan keyakinan mayoritas muslim. Sekte-sekte yang berkembang bukan lagi pengembangan atau perluasan dari sekte-sekte konvensional dalam Islam seperti qadiriyah, jabariyah, dan Asyariyah. Tetapi ada fenomena umum dimana kelahiran sekte, aliran atau cult adalah fenomena setiap agama, artinya setiap agama besar di dunia pasti selalu berurusan dengan lahirnya gerakan-gerakan, sekte-sekte yang menyimpang dari ajaran agama yang asli. Kemunculan aliran tersebut dengan berbagai perilaku beragama yang berbeda-beda.

Bahkan perkembangan sekte ini telah meneretas ke wilayah teologis-pluralis meskipun sebenarnya kelahiran sekte-sekte di indonesia bukanlah hal baru. Teologis pluralis yang dimaksud adalah bahwa sekte yang muncul berusaha untuk menggabungkan ajaran-ajaran agama yang ada menjadi satu keyakinan bersama, seperti halnya sekte Lia Eden.

\section{B. Madzhab Mainstream dan Penyebarannya}

Madzhab fikih adalah metode ijtihad dalam masalah-masalah furu' (bagian) syari'at Islam yang bertujuan mendekatkan hukum-hukumnya dan membuka jalan kepada hukum tersebut bagi kaum muslimin. 
Madzhab-madzhab fikih ini lahir dan tumbuh untuk merespon kebutuhan kaum muslimin terhadap pengetahuan tentang hukumhukum agama mereka dan menyiapkan hukum-hukum tersebut sebagai langkah antisipasi terhadap hadirnya masalah-masalah baru dalam kehidupan. Para tokoh atau imam mazhab seperti Abu Hanifah, Imam Malik, Imam Syafi'i, Ahmad bin Hanbal dan lainnya, masing-masing menawarkan kerangka metodologi, teori dan kaidah-kaidah ijtihad yang menjadi pijakan mereka dalam menetapkan hukum (Sirry, 1995: 61-65). Metodologi, teori dan kaidah-kaidah yang dirumuskan oleh para tokoh dan para Imam Mazhab ini, pada awalnya hanya bertujuan untuk memberikan jalan dan merupakan langkah-langkah atau upaya dalam memecahkan berbagai persoalan hukum yang dihadapi baik dalam memahami nash al-Quran dan al-Hadis maupun kasus-kasus hukum yang tidak ditemukan jawabannya dalam nash.

Metodologi, teori dan kaidah-kaidah yang dirumuskan oleh para imam mazhab tersebut terus berkembang dan diikuti oleh generasi selanjutnya dan ia -tanpa disadari- menjelma menjadi doktrin (anutan) untuk menggali hukum dari sumbernya. Dengan semakin mengakarnya dan melembaganya doktrin pemikiran hukum di mana antara satu dengan lainnya terdapat perbedaan yang khas, maka kemudian ia muncul sebagai aliran atau mazhab yang akhirnya menjadi pijakan oleh masingmasing pengikut mazhab dalam melakukan istinbat hukum.

Dengan demikian, terdapat dua pengertian mengenai madzhab, yakni: Pertama, mazhab adalah jalan pikiran atau metode yang ditempuh seorang Imam Mujtahid dalam menetapkan hukum suatu peristiwa berdasarkan kepada al-Qur'an dan hadis. Kedua, mazhab adalah fatwa atau pendapat seorang Imam Mujtahid tentang hukum suatu peristiwa yang diambil dari al-Qur'an dan hadis.

Yanggo (1995: 46) mengelompokkan mazhab-mazhab fiqih sebagai berikut: Pertama, Ahl al-Sunnah wa al-Jama'ah yang terdiri dari ahl al$R a ' y i$ (kelompok ini dikenal pula dengan Mazhab Hanafi) dan ahl al-Hadis (terdiri atas Mazhab Maliki, Mazhab Syafi'I, Mazhab Hambali). Kedua, Syi'ah yang terdiri dari Syi'ah Zaidiyah dan Syi'ah Imamiyah. Ketiga, Khawarij. Keempat, Mazhab-mazhab yang telah musnah, seperti Mazhab al-Auza'i, Mazhab al-Zhahiry, Mazhab al-Thabary, dan Mazhab al-Laitsi.

Secara mainstream, masyarakat muslim Indonesia lebih banyak menganut pada madzhab Syafii dari kalangan Sunni. Madzhab ini dikembangkan oleh Imam Syafi'I dimana beberapa organisasi Islam 
terbesar di Indonesia menjadikan madzhab Syafii sebagai landasan utama dalam praktek kehidupan keagamaan, khususnya dari organisasi Nahdlatu Ulama (NU) yang dikembangkan oleh Hasyim As'ary. Bahkan untuk meluruskan tentang bagaimana kita bermadzhab, mantan ketua NU dan sekaligus mantan presiden Republik Indonesia periode 20002002, KH. Abdurahman Wahid (Gus Dur) almarhum, menyatakan dalam ceramah-ceramahnya bahwa kami (warga NU) adalah madzhab Syafi'I secara metodologis, bukan secara kata-katanya. Di sini mengandung maksud bahwa dalam bermadzhab perlu ditekankan untuk lebih menggunakan metodologi sehingga terhindar dari taklid buta.

Meski demikian pemikiran dari beberapa madzhab yang lainnya juga masih dikembangkan pada kalangan muslim tertentu, seperti misalnya madzhab Hanafi, Maliki dan Hanbali. Pendiri mazhab Hanafi ialah: Nu'man bin Tsabit bin Zautha. Ia diliahirkan pada masa sahabat, yaitu pada tahun $80 \mathrm{H}=699 \mathrm{M}$. Beliau wafat pada tahun $150 \mathrm{H}$ bertepatan dengan lahirnya Imam Syafi'i R.A. Beliau lebih dikenal dengan sebutan: Abu Hanifah An Nu'man. Sedangkan Mazhab Maliki adalah merupakan kumpulan pendapat-pendapat yang berasal dari Imam Malik dan para penerusnya di masa sesudah beliau meninggal dunia. Terakhir, Madzhab Hanbali adalah madzhab yang dikembangkan oleh Imam ahmad Bin Hanbal.

Selain madzhab Syafi'i memang kurang begitu populer di Indonesia, namun beberapa karya dan pemikiran dari beberapa pengembang madzhab di atas banyak dijadikan rujukan di beberapa pesantren dan perguruan tinggi. Dengan demikian, meski secara formal hanya madzhab Syafi'i, namun secara metodologi dan pemikiran madzhab-madzhab selain Syafi'i ini juga diikuti oleh kaum muslimin di Indonesia.

\section{Sekte-Sekte dalam Islam}

Kalangan kaum Muslimin periode awal pasca meninggalnya Muhammad menjadi salah satu triger keanekaragaman teologi Islam, dan sekaligus menjadi titik tolak perkembangan literatur Islam. Merujuk ilustrasi Mahmoud Ayoub, “...Muslim history, properly speaking, begins not with the career of the Prophet, nor even with his migration, but with his death" (Ayoub, 2003: vii). Ayoub hendak menegaskan bahwa konstalasi politik pasca meninggalnya Rasulullah yang berimplikasi pada munculnya bibit perselisihan teologis dan bahkan pertentangan di kalangan kaum Muslimin pasca meninggalnya Nabi Muhammad. 
Munculnya Khawârij, disusul dengan perkembangan Syi'ah, Mu'tazilah, dan juga munculnya sekte-sekte Islam lainnya, telah menambah pengetahuan madzhab dan sekte di kalangan muslim masa ini.

Di sisi lain, keterangan-keterangan propetik (hadis) juga telah memberi ruang tersendiri bagi perkembangan kajian tentang heresiografi. Sebuah narasi tentang terjadinya perpecahan di kalangan umat muslim telah menjadi landasan utama para sejarahwan agama dan heresiograf Muslim awal. Tiga riwayat tentang perpecahan umat (iftirâq al-ummah) melalui "jalur" Abû Hurayrah, 'Abdullâh bin 'Umar dan Anas b. Malik acap menjadi landasan heresiograf Muslim.

Diriwayatkan oleh Abû Hurayrah, bahwasanya Rasulullâh Saw. bersabda: "Orang-orang Yahudi akan terpecah (iftaraqat) menjadi tujuh puluh-satu sekte, dan orang-orang Kristen akan terpecah menjadi tujuh puluh-dua sekte (firqah), sementara umatku akan terpecah (taftariqu) menjadi tujuh puluh-tiga sekte."

Diriwayatkan oleh Anas b. Malik, bahwasanya Rasulullâh Saw. bersabda: "Sesungguhnya Banî Isrâ'îl terpecah menjadi tujuh puluh-satu sekte (firqah), dan sesungguhnya umatku akan terpecah (sataftariqu) menjadi tujuh puluh-dua sekte (firqah), seluruh kelompok tersebut (kulluhâ) masuk neraka kecuali yang satu, yakni al-Jamâ'ah."

Di sini terlihat bahwa riwayat-riwayat tersebut nampaknya telah memberikan inspirasi bagi para teolog dan sarjana Muslim untuk menulis karya-karya heresiografi mereka, khususnya tentang sekte-sekte dalam Islam. Selanjutnya, persepsi dan penilaian Muslim awal terhadap agamaagama non-Islam berkembang menjadi sebuah telaah khusus yang di kemudian hari melahirkan karya-karya di bidang heresiografi. Muhammad Ali Amir-Moezzi, misalnya mencatat: Perkembangan konsep heresi dalam Islam dalam ekspresi intelektual dan literalnya dapat dilihat dengan adanya proses transisi dari "buku-buku penolakan" atau "pembuktian kesalahan" (kutub al-radd), dimana doktrin-doktrin agama dikemukakan dalam pola penjelasan yang menampilkan perbedaan, kepada sistematisasi yang lebih maju dari ortodoksi teologis dalam bentuk karya-karya heresiografis.

Beberapa karya heresiografi Islam antara lain ditulis oleh Abû alHasan al-Asy'arî (w. 935/936) melalui karyanya Maqâlat al-Islâmiyyîn wa Ikhtilâf al-Mushallîn (Opini-opini [teologis] Muslim dan Perselisihan Orang-orang Yang Salat) (al-Qâhirah, 1969: 70) dan al-Ibânah 'an al'Ushûl al-Diyânah (Uraian tentang Fondasi-fondasi Islam) (al-'Asy'ary). Al- 
Asy'arî sendiri merupakan pengikut Ahmad b. Hambal, dan belakangan mazhab Asy'ariyah menjadi salah satu mazhab teologi terbesar di kalangan Muslim. Al-Ghazâlî merupakan salah satu filsuf dan teolog besar dari mazhab ini. Karya-karya al-Asy'arî dalam bidang heresiografi ditulis setelah dia keluar dari mazhab Mu'tazilah karena ketidakpuasannya terhadap argument dan penjelasan teologis gurunya yang Mu'tazilah, alJubâ'î. Bila dalam Kitâb Maqâlat al-Asy'arî, dalam posisinya sebagai tokoh Sunnî, langsung menyusun daftar dan menganalisis kelompok-kelompok Islam "sempalan," seperti Khawârij, Zaidiyah, al-Ghulât, Rawâfid, Mu'tazilah, dan Murji'ah, maka dalam Kitâb al-Ibânah ia menyusun tematema pokok yang menjadi bahan perselisihan di dalam ilmu kalam. Nampaknya, Kitâb al-Ibânah merupakan komplemen terhadap Kitâb Maqâlat.

Karya lainnya adalah milik Abû Mansûr 'Abd al-Kâhir b. Tâhir alBaghdâdî (w. 1037), al-Farq Bayn al-Firaq (Skisme dan Sekte-sekte [dalam Islam]). Seperti al-Asy'arî, dalam bukunya ini al-Baghdâdî juga mengulas doktrin dan paham yang berkembang dalam sekte-sekte Islam yang telah disebut sebelumnya. Pada periode berikutnya, Abû alMuzhaffar Thâhir ibn Muhammad al-Isfarâynî menulis Tabsîr fí al-Dîn (Pencerahan tentang Agama). Dalam karyanya ini, al-Ishfarâynî tidak memberikan model sistematisasi maupun metodologi yang baru dari yang pernah ditulis al-Baghdâdî dalam menganalisis sekte-sekte Islam. Dari segi cakupan bahasan juga tidak ada perbedaan yang mencolok. Hanya saja, al-Isfarâynî menyertakan satu diskusi tentang kaum atheis (mulhidûn) selain memperjelas komitmennya sebagai penganut Sunni melalui pembahasan paham ahl- al-Sunnah wa al-Jamâ'ah di akhir pembahasan.

Al-Asy'arî, al-Baghdâdî, dan al-Isfarâynî adalah heresiograf awal yang merepresentasikan penulis-penulis Muslim Sunni, yang corak kajiannya sangat kental dengan judgment teologis terhadap kelompokkelomok non-mainstream. Al-Baghdâdî memberikan klasifikasi tersendiri tentang apa yang disebut dengan mazhab "sesat" atau "menyesatkan." Dia menilai bahwa perbedaan dalam bidang furu' yang menyebabkan munculnya mazhab-mazhab fiqih, masih dapat ditolerir selama mereka, para penganut mazhab-mazhab fiqih itu, masih dapat bersepakat dalam hal dasar-dasar agama (ushûl al-dîn). Sebaliknya, terdapat "kelompok terlarang" (al-farq al-madzmûmah) atau "penganut sekte yang sesat" (ashhâab al-ahwa' al-dhâllah), yakni mereka yang 
berbeda pendapat dari ahl al-sunnah wa al-jamấah dalam hal teologis. Dan konsep "sesat" tersebut dia tujukan kepada sekte-sekte yang terdapat dalam bukunya. Prinsip yang sama juga dipegang oleh alIsfarâynî yang tujuan penulisan bukunya adalah untuk mengidentifikasi sekte "sesat" (al-farq al-dhâllah) dan membedakan agamanya dari agama-agama lain "yang menyesatkan" ('an adyânihim al-dhâllah).

Karya para heresiograf Muslim tersebut setidak-tidaknya menjadi dasar bagi para heresiograf generasi berikutnya, seperti Ibn $\underline{\text { Hazm }}$ melalui Kitâb al-Fishl dan al-Syahrastânî yang menulis Kitâb al-Milal. Berbeda dengan ketiga heresiograf sebelumnya yang "Sunni murni," Ibn Hazm sendiri dikenal sebagai penganut mazhab Dzâhirî (literaliseksternalis), sedangkan al-Syahrastânî adalah teolog dan filsuf besar Asy'ariyah yang "dicurigai" menganut atau setidaknya bersimpati kepada 'Ismâ'îliyah. Sementara al-Bîrûnî tidak menelurkan karya heresiografi secara khusus, ia bahkan lebih dikenal sebagai seorang ilmuan di bidang geografi, matematika, dan sejarah ketimbang sebagai heresiograf. Faktorfaktor inilah yang membedakan mereka dengan para sejarahwan, penulis, dan teolog Muslim sebelumnya.

Dengan demikian sebetulnya kebanyakan persepsi, cara pandang, dan bahkan metodologi yang digunakan kaum Muslim dalam mencermati agama dan sekte agaknya tidak bisa dilepaskan dari teori dan cara pandang yang telah berkembang sejak abad pertengahan Islam ketika agama-agama dan sekte-sekte menjadi salah satu isu sentral. Meskipun demikian, berdasarkan pada observasi awal di atas, karya-karya Muslim tersebut tidak melulu dilatar belakangi oleh motif yang sama. Setidaknya sebagian menulis tentang agama-agama dan sekte-sekte sebagai bagian dari catatan perjalanan para pedagang maupun pengembara, sehingga perspektif yang dibangun ketika menganalisa agama-agama di luar Islam tersebut tidak semata-mata teologis. Sementara itu, sebagian lainnya memang ditulis khusus untuk mengupas agama-agama dan sekte-sekte yang ada, dan ditujukan untuk mengoreksi atau mengritik banyak hal, terutama pada sisi teologis.

Bila kita cermati lebih jauh, dan tentu harus diteruskan dengan penelaahan dan penelitian lanjutan, cara pandang kaum Muslim tersebut mengerucut pada dua kutub yang sampai saat ini masih belum dapat disatukan sepenuhnya, yakni kutub yang bercorak deskriptif-analitik, dan kutub lainnya yang bersifat teologis-polemis. Deskripsi di atas setidaknya sudah memetakan bagaimana manifestasi kedua kutub 
tersebut dalam studi agama dan sekte. Artinya konsep-konsep teoretis tentang bagaimana kaum Muslim mempersepsikan agama-agama lain dapat titemukan dalam karya-karya Muslim klasik.

Literatur Muslim Abad Pertengahan tentang agama dan sekte adalah bahwa munculnya hereisograf Muslim tidaklah terhenti pada era tersebut, melainkan di era modern pun akan senantiasa muncul sektesekte baru dan bahkan agama-agama baru yang kemudian disusul oleh munculnya heresiograf-heresiograf baru, baik dalam bentuk personal maupun kelembagaan. Dewasa ini, tidak jarang respons negatif dan bahkan 'represif' dengan melibatkan tindak kekerasan dari kelompokkelompok keagamaan arus utama terhadap sekte-sekte atau aliran keagamaan yang dianggap "sesat." Dan itu semua adalah salah satu bentuk konsekuensi dari teori dan praktik heresiografi yang dianut oleh masyarakat saat ini.

\section{Sekte-sekte Menyimpang di Indonesia}

Fenomena kelahiran sekte, aliran atau cult adalah fenomena setiap agama, artinya setiap agama besar di dunia pasti selalu berurusan dengan lahirnya gerakan-gerakan, sekte-sekte yang menyimpang dari ajaran agama yang asli. Kemunculan aliran tersebut dengan berbagai perilaku beragama yang berbeda-beda. Ada sekedar berkumpul dan bersemedhi sampai ada yang menyelenggarakan bunuh diri massal. Ada yang bersifat tidak merugikan akan tetapi ada yang sangat merugikan orang lain dengan tindakan-tindakan kekerasan. Masyarakat Indonesia pun tidak lepas dari fonemena ini, masih lekang dalam ingatan kasus Lia Aminuddin dengan Gerakan Taman Edennya, gerakan ingkar sunnah atau Quran Suci, sekte hari kiamat, ahmadiyah, aliran bahai, dll.

Dalam konteks teologi, keberadaan sekte-sekte tersebut mungkin dapat dikatakan sesat, karena memang menyebarkan ajaran-ajaran yang menyimpang dari wacana Islam mainstream. Namun, secara sosiologis, fenomena ini sebenarnya dapat dianggap sebagai kejadian yang biasa dalam kehidupan beragama, karena ia sudah muncul semenjak Islam pada masa-masa awal, meskipun ajaran dan pola gerakannya berbeda.

Maraknya sekte-sekte keagamaan tersebut sebenarnya dapat dianggap sebagai kritik terhadap institusi dan tradisi agama-agama formal di Indonesia yang cenderung menekankan aspek legal-formalnya saja. Penekanan yang berlebihan pada sikap kepatuhan dan ketundukan 
di hadapan ajaran agama disadari atau tidak telah melahirkan lubang menganga dalam kehidupan beragama, terutama dalam wilayah psikologis para penganutnya, karena hidup beragama sejatinya tidak hanya berurusan dengan aspek-aspek legal-formal semata, tetapi juga melibatkan aspek penghayatan dan pemaknaan. Jika agama formal dianggap tidak lagi mampu mengakomodasi kebutuhan-kebutuhan psikologis dan menjamin kenyamanan para penganutnya, secara alamiah akan lahir cara-cara beragama baru yang menjanjikan pemenuhan kebutuhan-kebutuhan tersebut.

Untuk itu, kritik di atas semestinya dapat disikapi secara dewasa, karena tidak dapat ditampik bahwa kelahiran sekte-sekte tersebut berasal dari rahim agama-agama formal itu sendiri. Dengan kata lain, kehadirannya adalah semacam otokritik bagi agama-agama. Jika disikapi secara dewasa dan bijak, kehadiran sekte-sekte tersebut sebenarnya dapat menjadi stimulus bagi agama-agama formal untuk merevitalisasi diri agar tidak ditinggalkan oleh umatnya.

Fakta sosial yang menunjukkan bahwa hampir semua sekte keagamaan di Indonesia lahir di kota-kota besar (Jakarta; Lia Eden, Bogor (Mushodeq), Yogyakarta (Satria Piningit), dll.) adalah indikasi lain bahwa agama-agama formal masih kurang responsif terhadap kebutuhan keberagamaan warga kota. Hidup di tengah rutinitas, ekspektasi sosial, dan persaingan yang ketat di kota besar membuat orang tertekan secara psikologis, sehingga secara alamiah mereka mengupayakan jalan keluar untuk mencari sumber-sumber kenyamanan dan kebahagiaan. Belum lagi ketika setiap hari warga kota selalu disuguhi perilaku para pemimpin yang tidak bertanggung jawab, sehingga ekspresi keagamaan dalam wadah sekte-sekte ini dapat dianggap sebagai ekspresi ketidakpercayaan terhadap figur-figur pemimpin formal, baik pemimpin agama maupun politik.

\section{E. Faktor-Faktor Penyebab Sekte Menyimpang}

\section{Adanya klaim dari seseorang yang mendapat wahyu}

Hampir semua sekte yang menyimpang berawal dari klaim seseorang yang menganggap dirinya mendapatkan wahyu atau kepercayaan dari Sang Pencipta. Bahkan ada sebagian di antara pemimpin sekte yang menganggap dirinya sebagai Tuhan karena adanya konsep ittihad (penyatuan) antara dirinya dengan Tuhan.

\section{Adanya kultus terhadap imam (al-ghulwu fi ta'dzimi al-imah)}


Penyimpangan beberapa sekte di Indonesia (contoh; Lia Aminuddin dan Ahmad Moshadeq) sebenarnya merupakan gejala kultus. Gejala kultus adalah bentuk gerakan keagamaan yang dicirikan dengan sistem pengorganisasian yang ketat, absolutistik, disiplin, dan, dengan sendirinya kurang toleran dengan kelompok lain. Kultus biasanya berpusat pada ketokohan seorang pribadi yang menarik, berdaya pikat retorik yang memukau, yang secara sederhana menjanjikan keselamatan dan kebahagiaan. Seringkali hal ini diikuti dengan pemaksaan, ketertutupan, dan pengorbanan harta dan jiwa yang tidak proporsional. Sampai tingkat tertentu, fenomena kultus ini menjadi sangat antisosial, bahkan menjerumuskan pengikutnya pada psikologi "ingin mati."

\section{Pengaruh Modernisasi}

Dampak negatif modernisasi seperti individualisme, saling acuh, tidak adanya kepedulian sosial, hilangnya struktur kemasyarakatan yang kokoh, dan kaburnya makna yang berlaku; mengakibatkan masyarakat larut dalam kesepian dan kekeringan ruhani. Keterasingan inilah yang kemudian membuat mereka tertarik pada kultus-kultus/sekte. Sebab, keterasingan (alienasi) menimbulkan kesepian mencekam, lalu merindukan perkawanan akrab dan hangat, serta mendambakan penjelasan/penegasan makna hidup. Hal ini seolah menemukan salurannya dalam sekte. Solidaritas dan kepedulian kelompok yang tinggi, serta persaudaraan yang hangat, adalah fenomena khas yang didapati dalam semua sekte keagamaan. Pukauan inilah yang membuat para pengikut sekte dapat begitu setia mematuhi ajaran pemimpinnya, dengan mengabaikan akal sehat dan pendapat mayoritas. Ini berlaku bahkan untuk mereka yang telah mengenyam pendidikan tinggi-seperti pengikut Lia Aminuddin yang berlatar belakang jurnalis, dosen, juga para teknokrat kaya.

Alhasil, fenomena aliran sesat bukan semata disebabkan keawaman ilmu pengetahuan/agama, tetapi lebih banyak karena hubungan dan kepedulian sosial yang rapuh. Ahmad Moshadeq telah tobat. Lia pun telah dipenjara. Tapi bukan berarti ancaman sosial dari sekte sesat semacam itu usai. Ia telah menjadi bahaya laten.

\section{F. Catatan Penutup}

Perkembangan wacana madzhab dan sekte memiliki pola yang berbeda. Perkembangan madzhab masih berputar dalam ranah Islam, 
meskipun dalam beberapa kasus terjadi pertentangan antara satu madzhab dengan madzhab lainnya. Dari segi formal, mayoritas muslim di Indonesia adalah madzhab Syafii. Namun secara substansial, beberapa madzhab yang lainnya juga dikaji, dipelajari bahkan diterapkan oleh sebagian muslim di Indonesia, terutama dari kalangan yang mengerti agama (ulama, intelektual, dan para sarjana). Bahkan perkembangan madzhab di Indonesia bukan lagi terkonsentrasi hanya pada Sunni (Syafi'i, Maliki, Hanafi dan Hambali), tetapi juga pemikiran-pemikiran dari Syiah yang mulai marak sejak tahun 90-an yang dicirikan oleh merebaknya beberapa buku Syiah di indonesia.

Sementara perkembangan sekte-sekte dalam Islam secara sosialreligius, berkorelasi dengan perkembangan pengetahuan, keyakinan dan dinamika sosial keagamaan masyarakat. Dalam perkembangan sektesekte, terdapat fenomena yang dinamis dan progresif. Bahkan dinamika yang muncul kerap melampaui nalar dan keyakinan mayoritas muslim. Sekte-sekte yang berkembang bukan lagi pengembangan atau perluasan dari sekte-sekte konvensional dalam Islam seperti qadiriyah, jabariyah, dan Asyariyah. Namun perkembangan sekte ini telah meneretas ke wilayah teologis-pluralis. Meski demikian, fenomena bermunculannya berbagai sekte belakangan ini di Indonesia sebenarnya perluasan dari praktek praktek "Aliran Kebatinan" dimana praktek aliran itu didasari oleh keyakinan adanya pengalaman batin seorang pemimpin sekte yang mendapati wahyu ilahi melalui malaikat.[]

\section{DAFTAR PUSTAKA}

Abû al-ㅂasan 'Alî b. 'Ismâ'îl al-'Asy'arî. (1969-70). Maqâlat al-Islâmiyyîn wa Ikhtilâfal-Mushallîn. bi-tahqîiq Muhammad Muhyî al-Dîn 'Abd alHamîd. Al-Qâhirah: Maktabat al-Nahdhah al-Mishriyyah

Ayoub, Mahmoud M. (2003). The Crisis of Muslim History: Religion and Politics in Early Islam. Oxford: Oneworld 
al-'Asy'arî. (t.th.). al-Ibânah 'an al-Ushul al-Dayânah, taqdîm wa-tahquîq wa-ta'lî́q Fawqiyyah Husayn Mạhmûd. Beirut: Dâr al-Kutub al'Ilmiyyah.

Imbabi, M. Musthofa. (1986). Tarikh Tasyri' al-Islami. Kairo: Al-Maktabah Al-Tijariyyah Al-Kubro

Ismail, Ahmad Satori. (2003). Pasang Surut Perkembangan Fiqh Islam. Jakarta: Pustaka Tarbiatuna

Madelung, Wilfred. (1997). The Succession to Muhammad. Cambridge: Cambridge University Press

Nasution, Harun. (2002). Teologi Islam Aliran-aliran Sejarah Analisa Perbandingan. Jakarta: UI Press

Sirry, Mun'im A. (1995). Sejarah Fiqh Islam. Surabaya: Risalah Gusti

Yanggo, Huzaemah Tahido. (2003). Pengantar Perbandingan Mazhab. Jakarta: Logos 